\title{
Structural and Green Infrastructure Mitigation Alternatives Prevent Ciliwung River from Water-related Landslide
}

\author{
Rian Mantasa Salve Prastica,"\#, Riko Apriatresnayanto", Dwinanti Rika Marthanty \\ * Civil Engineering Department, Universitas Gadjah Mada, Yogyakarta, 55281, Indonesia \\ E-mail: rian.mantasa.s.p@ugm.ac.id \\ ${ }^{\#}$ Civil Engineering Department, Universitas Indonesia, Depok, West Java, 16424, Indonesia \\ E-mail: ${ }^{1}$ riko140480@gmail.com,and ${ }^{2}$ dwinanti@eng.ui.ac.id
}

\begin{abstract}
Landslide is one of the most dangerous hazards worldwide. It could be caused by several factors and could have a massive destructive impact on the environment. A landslide event occurred in one of the urban cities in Indonesia. In the middle of 2002, a landslide disaster due to rainfall occurred in the Ciliwung River's floodplain, precisely in the South Jakarta area. The landslide profoundly affected large areas of the region and seriously injured many people. Several circumstances that could trigger landslide occurrences are the building load in the settlement area around the river, increase in the rainfall intensity, slope, and soil characteristics in the Ciliwung River area. This research proposes a combination of nonstructural and structural disaster mitigation methods for water-related landslide by investigating the safety factor (SF) of the river bank's slope in one of the impacted sites, i.e., the area under the main bridge of Grand Depok City regency. This site is located in the boundary area between Depok City and South Jakarta. The authors simulate analytical and numerical modeling to estimate the SF of the slopes. This research concludes that the minimum SF in the analyzed location is recognized as a safety criterion for society. The condition becomes less secure when an earthquake occurs. Furthermore, high rainfall intensity could become the worst scenario that generates considerable damage. The proposed structural mitigation for river bank with anchor or snail increases the SF. However, this reinforcement program is not recommended because of its high cost and ineffectiveness in solving problems. Hence, green infrastructure (GI) is highly suggested for nature-based mitigation to prevent rainfall-triggered landslides in the Ciliwung River area. The authors conduct the preliminary design of the study and recommend further analysis of GI or soil bioengineering to ensure its effectiveness and applicability in the research area.
\end{abstract}

Keywords - water-related disaster; Ciliwung river; green infrastructure mitigation; disaster management.

\section{INTRODUCTION}

People worldwide face various environmental hazards. Many people are injured or killed in different areas. We could not deny that these hazards are influenced by both natural and human factors. Moreover, mass media have reported that these hazards affect not only developing countries but also developed countries. The government could prevent some hazards; however, other hazards are unavoidable. Furthermore, the lack of intervention to protect people from these environmental hazards could be observed in developing countries, such as Indonesia.

Indonesia has faced many hazards, particularly landslide disasters, in the past decades. The National Disaster Management Authority (BNPB) recorded 1,287 landslide events that occurred in all provinces in Indonesia from 2000 to 2011. The number of accidents further increased in 2018. For instance, West Java has had a high number of landslide disaster events. In 2011, the Regional Disaster Management Agency (BPBD) recorded 11 regions in West Java that faced landslides.

Landslide has become the most damaging environmental hazard [1-6], and the main triggering factors of this hazard are rainfall [7-13] and earthquakes [14-16]. A problem in the analysis of water-related landslide is the lack of data on rainfall-triggered landslide (RTL). The data previously recorded in several areas are shown in Table 1 . The increasing number of avalanche in recent years showed that the improvement in the collection of RTL data has not been achieved.

The reduction of the impact of disasters could be analyzed by quantitative methods [17]. The analysis covers hydraulic engineering, geotechnical engineering, ecological engineering, and other multidisciplinary fields. This research aims to mitigate the RTL that occurred in the Ciliwung River by quantifying and assessing the safety factor (SF) in the 
initial step. Then, structural mitigation and green infrastructure (GI) for landslide mitigation is analyzed to select a better policy.

Ciliwung River flows through Bogor, Depok, and Jakarta. According to Silviani [18], the hazard level in Ciliwung watershed ranges from low to high. The medium hazard level covers $54.89 \%$ of the total area. By contrast, the high hazard level covers $10.08 \%$ and the low hazard level covers $34.77 \%$ of the total area. This research uses Depok City as the study area. Depok City is categorized as a city with a medium hazard level. The vulnerability of Ciliwung watershed is at the medium level (i.e., $53.25 \%$ of the total area). The factor that triggers this result is the large population in Ciliwung watershed. On the basis of the economic factor, the annual income is lower than 1,000,000 rupiah. In terms of the physical condition, the vulnerability level is caused by the high building density. In terms of the environmental aspect, landslide events increase the vulnerability level.

Furthermore, land usage vulnerability is caused by the distribution of settlements. Moreover, the exposure level of Ciliwung watershed is high. Therefore, the risk level of Ciliwung watershed to RTL varies from low to high. The dominant risk level in the basin is the high level. Thus, disaster risk reduction analysis of water-related landslide should be conducted. The authors aim to analyze disaster risk reduction of RTL in Ciliwung River.

In the middle of 2002, a landslide disaster due to rainfall occurred in the Ciliwung River's floodplain, precisely in the South Jakarta area. The authors propose a disaster risk reduction method for RTL in Ciliwung watershed. Soil data availability is needed to make a comprehensive analysis. The authors utilize Depok City as a model city for disaster risk reduction by proposing different types of mitigation methods. The final decision on the type of mitigation method is based on the SF of Ciliwung River's floodplain.

\section{TABLE I}

RAINFALL-TRIGGERED LANDSLIDE RECORDS. A: IMPACTED AREA $\left(\mathrm{KM}^{2}\right)$; T: EVENT TOTAL RAINFALL (MM); D: DURATION (H); I: MAXIMUM RAINFALL INTENSITY (AS WATER HEIGHT-DURATION REPORTED BY THE AUTHORS, MM-H); L: NUMBER OF TRIGGERED LANDSLIDES; V: NUMBER OF VICTIMS

\begin{tabular}{|l|l|l|l|l|l|l|l|}
\hline Location & A & Date & T & D & I & L & V \\
\hline $\begin{array}{l}\text { Hong } \\
\text { Kong [19] }\end{array}$ & 1,050 & $5 / 92$ & $>350$ & 24 & $\begin{array}{l}25- \\
0.08\end{array}$ & $>300$ & 3 \\
\hline $\begin{array}{l}\text { Hong } \\
\text { Kong [20] }\end{array}$ & 1,050 & $8 / 76$ & 500 & 24 & $82-1$ & 314 & 57 \\
\hline Japan [21] & 140 & $9 / 71$ & 559 & 62 & $122-1$ & 7,760 & 56 \\
\hline $\begin{array}{l}\text { Virginia } \\
\text { [22] }\end{array}$ & $\begin{array}{l}\text { Approxi- } \\
\text { mately 100 }\end{array}$ & $6 / 95$ & 770 & 16 & $64-5$ & Hundreds & 0 \\
\hline
\end{tabular}

On the basis of the problem background, the research aims to obtain a better solution to mitigate the occurrence of RTL in the Ciliwung River.

\section{MATERIAL AND METHOD}

Methods to analyze slope stability have been proposed worldwide. Researchers are familiar with both conventional and advanced techniques. In geotechnical engineering, the limit equilibrium method has become the most well-known and widely used traditional method to compute slope stability. This method is easier to use than other advanced methods, such as finite element analysis. This research uses both conventional and advanced techniques to describe the slope stability condition in the Ciliwung River for sustainable development.

The conventional method is currently the most used method. The purpose of slope stability analysis using the conventional method concerns SF computation. Some techniques are available for circular slip surfaces only [23, 24]. Furthermore, the developed method could be used for any shape of slip surfaces [25-28]. These methods have different problem solutions according to the equilibrium condition that it fulfills. This research explains several methods. For instance, the method of slices [23] satisfies only the moment of equilibrium. Bishop's modified method [24] can compute the moment equilibrium and vertical force equilibrium. Morgenstern and Price's method [25], Janbu's generalized procedure of slices [29], Sarma's method [30], and slope stability chart can be used to analyze all conditions of equilibrium but differ from each other in terms of their assumptions about interslice forces. This research uses several methods, namely, ordinary method of slices, Bishop's modified method, and Janbu's method. Hence, the SF is an essential part of slope stability before taking mitigation into account.

In addition to the conventional method, researchers have developed advanced analysis using a numerical method. The basic computation of the method involves finite element analysis that is improved using several programs, such as SLOPE/W, Plaxis, and other supporting applications.

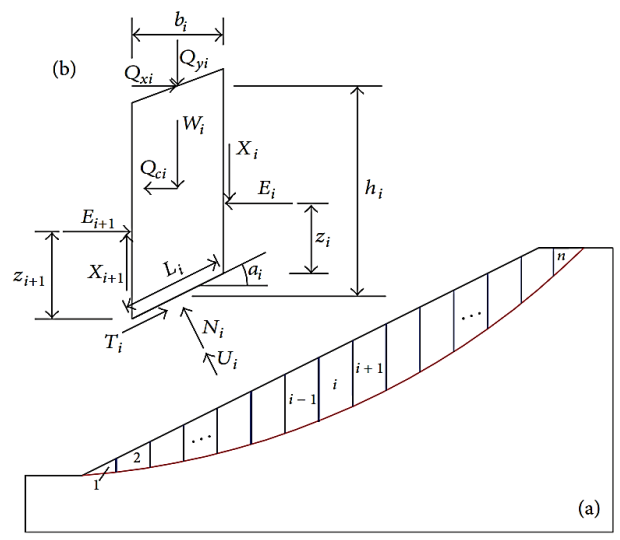

Fig. 1 Sketch of the slope cross section and forces acting on the $i$ th slice Source: Zhao [31]

Mitigation is one of the essential cycles of disaster management. Two mitigation methods are proposed in this research. Structural reduction could be determined if slope stability is analyzed. We can increase the SF after considering several things, namely, natural resources, human resources, and budget. GI could be used to be mitigate landslides around the river's floodplain. Hence, the authors aim to advance structural mitigation and GI for landslide mitigation.

One of the fundamental assumptions about slope stability analysis is acquired from Zhao [31]. The limit equilibrium method divides slip surface and free ground surface into $n$ 
slices as shown in Fig. 1(a). The main forces acting on the $i$ th slice (Fig. 1(b)) are the weight $\left(W_{i}\right)$, horizontal earthquake force $\left(Q c_{i}\right)$, horizontal and vertical loads $\left(Q x_{i}\right.$, $\left.Q y_{i}\right)$, water pressure $\left(U_{i}\right)$, interslice forces $\left(E_{i}, X_{i}, E_{i+1}, X_{i+1}\right)$, normal force $\left(N_{i}\right)$, and sliding force $\left(T_{i}\right)$ of the slip surface.

This research computes the slice-wise factor as the ratio of the anti-sliding force to the sliding force. It is the same as the concept of shear strength reduction [32].

$$
F_{i}=\frac{N_{i} \tan \phi_{i}+c_{i} b_{i} \sec \alpha_{i}}{T_{i}}
$$

where $c_{i}$ is the shear strength parameter of the slip surface and $b_{i}$ is the width of the slice.

The rigorous Janbu's method [29] suggests that the height of the thrust line is between one third and one half of the height of the slice's profile. Furthermore, the equilibrium of the forces and boundary conditions will be discussed. As shown in Fig. 1, we determine the horizontal and vertical equilibrium of the forces.

$$
\begin{aligned}
& E_{i+1}+T_{i} \cos a_{i}-N_{i} \sin \alpha_{i}= \\
& E_{i}+\left(Q_{c_{i}}+U_{i} \sin \alpha_{i}-Q_{x_{i}}\right) \\
& X_{i+1}+N_{i} \cos \alpha_{i}-T_{i} \sin a_{i}= \\
& X_{i}+\left(W_{i}+Q_{y_{i}}-U_{i} \cos \alpha_{i}\right)
\end{aligned}
$$

The SF for all of the previous steps [31] could be expressed as the ratio of the total anti-sliding force to the amount of the sliding force on the slip surface.

$$
F=\frac{\sum_{i=1}^{n} R_{i}}{\sum_{i=1}^{n} T_{i}}
$$

where:

$$
R_{i}=N_{i} \tan \phi_{i}+\frac{c_{i} b_{i}}{\cos \alpha_{i}}
$$

The proposed slope stability analysis [31] could satisfy all of the equilibrium conditions of forces and moments. Table 2 shows the comparison of the SF results obtained using the method proposed by Zhao [31].

TABLE II

COMPARISON OF THE SAFETY FACTOR (SF) RESULTS

\begin{tabular}{|l|l|l|}
\hline Calculation method & SF experiment 1 & SF experiment 2 \\
\hline $\begin{array}{l}\text { Morgenstern and } \\
\text { Price's method }\end{array}$ & 0.991 & 1.261 \\
\hline Bishop's method & 0.992 & 1.258 \\
\hline Janbu's method & 0.963 & 1.199 \\
\hline Zhao's method & 0.996 & 1.247 \\
\hline
\end{tabular}

Zhao's method [31] and Morgenstern and Price's method [25] seem to have the best solution to compute the SF. However, this research aims to calculate slope stability using Bishop's method [24, 33] and Janbu's method [29, 33]. Despite the introduction of a new advanced method, the slice method is still the most well-known and widely used to estimate the SF [34]. Pereira et al. [35] compared several methods of slope stability analysis and determined that the simplified Bishop, simplified Janbu, and Bishop methods have the optimum performance, with the correlation coefficient of $99 \%$ for the simplified Bishop. The authors still consider the limitation of the definition of the SF in traditional slice methods and do not introduce new concepts of the slice-wise SF and limit equilibrium method. In addition to the ease of calculation, the authors will compare the results of the two aforementioned methods with that of the modeling approach, i.e., Geo-Slope, which still adopts several methods, namely, Janbu's method [29, 36], Bishop's method [24], Morgenstern and Price's method [25], and Spencer's method [26]. Tables 3 and 4 present the equations of statics satisfied and the interslice force characteristics and relationships, respectively.

Various commercial packages have been used to compute slope stability, for example, GEO05 [37], SLIDE [38], and SLOPE/W [39]. This research uses SLOPE/W as a supporting tool to analyze slope failure. The analysis using SLOPE/W, that is, Geo-Slope, has two limitations. First, the program could not consider the local variations. Second, the computed stress distributions are often unrealistic. These two are the fundamental pieces of missing physics that could lead to better result analysis. However, the method proposed by Zhao et al. [31] is still not declared as the governing equation of this program. Furthermore, the authors recommend the latest method to be considered as the input concept in geotechnical solution modeling programs, such as Geo-Slope.

TABLE III

EQUATIONS OF STATICS SATISFIED

\begin{tabular}{|l|l|l|}
\hline Method & Moment equilibrium & Force equilibrium \\
\hline Janbu & No & Yes \\
\hline Bishop & Yes & No \\
\hline $\begin{array}{l}\text { Morgenstern } \\
\text { and Price }\end{array}$ & Yes & Yes \\
\hline Spencer & Yes & Yes \\
\hline
\end{tabular}

TABLE IV

INTERSLICE FORCE CHARACTERISTICS AND RELATIONSHIPS

\begin{tabular}{|l|l|l|l|}
\hline Method & $\begin{array}{l}\text { Interslice } \\
\text { normal } \\
(\mathbf{E})\end{array}$ & $\begin{array}{l}\text { Interslice } \\
\text { shear }(\mathbf{X})\end{array}$ & $\begin{array}{l}\text { Inclination of X/E } \\
\text { resultant and X-E } \\
\text { relationship }\end{array}$ \\
\hline Janbu & No & Yes & Horizontal \\
\hline Bishop & Yes & No & Horizontal \\
\hline $\begin{array}{l}\text { Morgenstern } \\
\text { and Price }\end{array}$ & Yes & Yes & $\begin{array}{l}\text { Variable; user } \\
\text { function }\end{array}$ \\
\hline Spencer & Yes & Yes & Constant \\
\hline
\end{tabular}

Equations (4) and (5) are the SF formulas of Bishop's method and Janbu's method, respectively. Janbu's method is the as same as Bishop's method. However, it (1) considers normal interface forces but ignores interslice shear forces and (2) satisfies the overall horizontal force equilibrium.

$$
F S=\frac{1}{\sum W \sin \alpha} \sum\left[\frac{c \beta+W \tan \phi-\frac{c \beta}{F S} \sin \alpha \tan \phi}{m_{\alpha}}\right]
$$

where:

$$
m_{\alpha}=\cos \alpha+\frac{\sin \alpha \tan \phi}{F S}
$$




\section{RESULTS AND DISCUSSION}

\section{A. Study Area}

In the middle of 2002, a landslide disaster occurred in the Ciliwung River's buffer, precisely in the South Jakarta area. The landslide profoundly affected large areas of the region and seriously injured many people. Before this disaster, landslide events in the Ciliwung River's buffer occurred several times. However, these events did not injure anyone. Several factors that could trigger landslide events are the building load in the settlement area around the river, increase in the rainfall intensity, slope, and soil characteristics in the Ciliwung River area. In this research, the authors aim to analyze the SF of the buffer's slope in the Grand Depok City (GDC) bridge. The bridge is located in Depok City, West Java, Indonesia. Fig. 2 depicts the observed location.

\section{B. Soil Data}

The initial step of this analysis is taking soil samples from the location of the research area. Three samples are taken from each sampling location. Then, the three soil samples are observed in the soil mechanics laboratory of Universitas Indonesia. Table 5 lists the soil parameters of GDC bridge.

\section{Slope Stability Analysis}

First, the GDC bridge slope stability is analyzed using Bishop's method, Janbu's method, Plaxis, and Geo-Slope modeling approach.

For Bishop's method, four scenarios, namely, without intervention condition, intervention/loading condition, flood or groundwater influence condition, and seismic condition, are analyzed. Table 6 shows the result of the slope stability SF analysis of GDC bridge using Bishop's method.

Janbu's method determines the SF on two sides of the bridge, i.e., Citayam and GDC sides. Table 7 shows the result of the slope stability SF analysis of GDC bridge using Janbu's method.

On the basis of the SF analysis result, this study proposes both structural and nonstructural disaster mitigation methods.

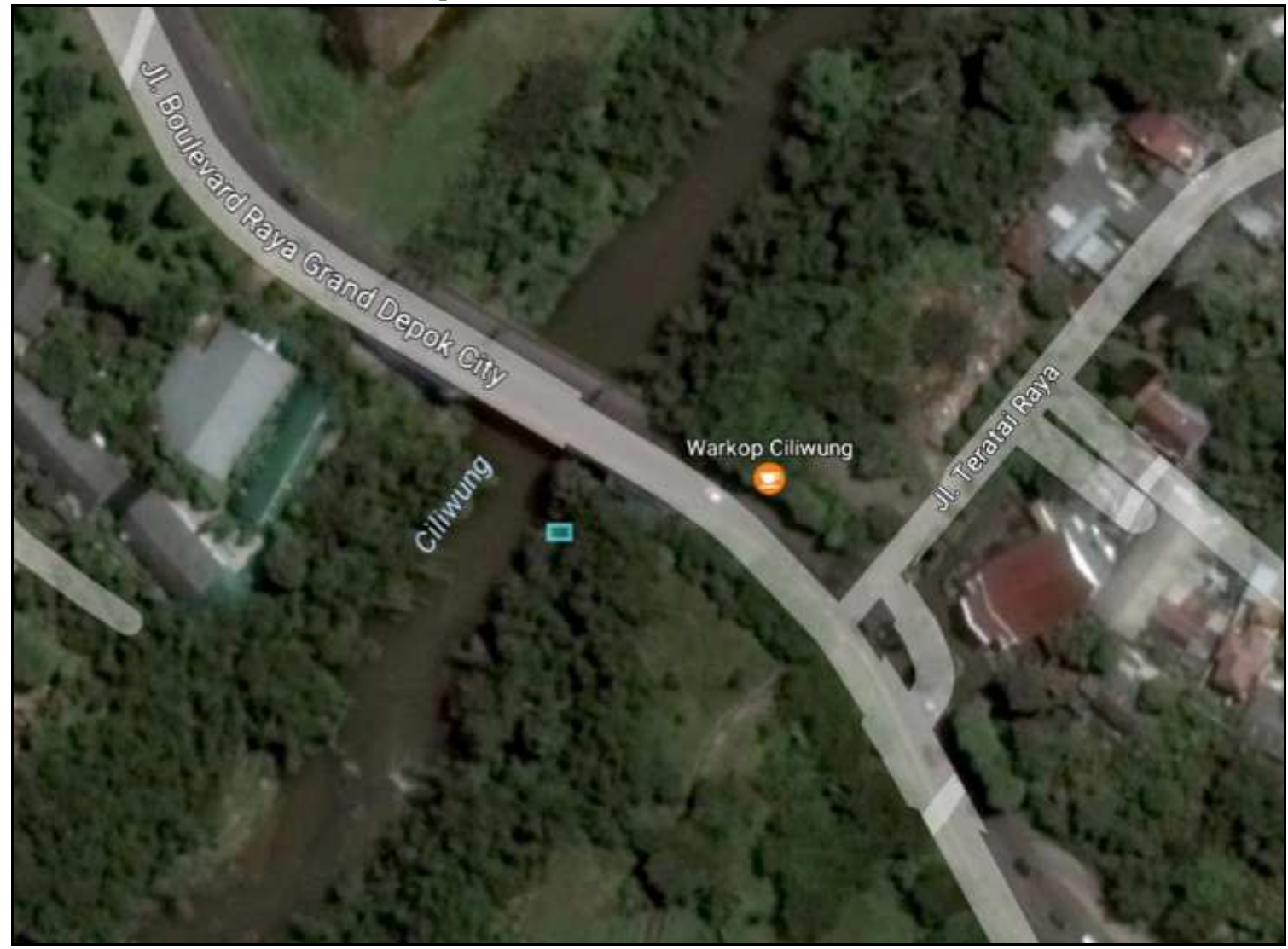

Fig. 2 Location of the Grand Depok City bridge

The authors also used Plaxis 8.2 to analyze the displacement of the slope. This alternative method has been widely used, for example, by Kumar et al. [46]. This method based on finite element analysis is proven to compute and model slope stability. This research assumes several necessary calculations for this location. The model is made using 15 nodes and assumed to be a plane strain model. The soil parameters are analyzed using the Mohr-Coloumb model. Then, the undrained concept is used to analyze this model. The external load is $20 \mathrm{kN} / \mathrm{m}^{2}$, and the Poisson ratio is 0.3 . The pore water pressure is $9.8 \mathrm{kN} / \mathrm{m}^{3}$, and the soil elasticity modulus $(E)$ is $15,000 \mathrm{kN} / \mathrm{m}^{2}$. On the basis of the
Plaxis 8.2 program analysis results shown in Fig. 3, the value of soil deformation is $313 \mathrm{~mm}$ with global landslide potential on both sides.

Finally, the slope stability in the GDC bridge location is modeled with Geo-Slope. The authors assume that both sides of the bridge's slope, i.e., Citayam and GDC sides, will be computed differently in terms of global collapse, upper local collapse, and sub-local collapse. Figs. 4, 5, and 6 depict the program results. The computation considers both with and without seismic conditions. Table 8 shows the result of slope stability SF analysis of GDC bridge. 
TABLE V

SOIL PARAMETERS OF GRAND DEPOK CITY (GDC) BRIDGE

\begin{tabular}{|l|l|l|l|}
\hline Parameter & $\begin{array}{l}\text { Citayam } \\
\text { side }\end{array}$ & GDC side & Source \\
\hline Soil type & ML/OL & CH/OH & ASTM/USCS \\
\hline Liquid index & 0.9868 & 0.99851 & Laboratory test \\
\hline Plastic index & 14.11 & 13.47 & Laboratory test \\
\hline $\mathrm{Su}$ & $25 \mathrm{kPa}$ & $20 \mathrm{kPa}$ & $\begin{array}{l}\text { Terzaghi et al. } \\
\text { [40] }\end{array}$ \\
\hline$\sigma^{\prime}$ & $23.426 \mathrm{kPa}$ & $15.015 \mathrm{kPa}$ & Skempton [41] \\
\hline $\mathrm{OCR}$ & 1.25 & 1.2 & Bjerrum [42] \\
\hline$\phi$ & $27^{\circ}$ & $28^{\circ}$ & Gibson [43] \\
\hline$E$ & $15 \mathrm{MPa}$ & $15 \mathrm{MPa}$ & $\begin{array}{l}\text { Soil type: clay; } \\
\text { Wesley [44] }\end{array}$ \\
\hline$\gamma_{\text {sat }}$ & $18 \mathrm{kPa}$ & $18 \mathrm{kPa}$ & $\begin{array}{l}\text { Budhu [45]; } \\
\text { Appendix A }\end{array}$ \\
\hline$\gamma_{d r y}$ & $16 \mathrm{kPa}$ & $16 \mathrm{kPa}$ & $\begin{array}{l}\text { Budhu [45]; } \\
\text { Appendix A }\end{array}$ \\
\hline
\end{tabular}

TABLE VI

SF ANALYSIS OF GDC BRIDGE USING BISHOP'S METHOD

\begin{tabular}{|l|l|}
\hline Condition & SF \\
\hline Without intervention & 2.69 \\
\hline With loading intervention & 2.65 \\
\hline Groundwater infiltration & 1.33 \\
\hline Seismic condition & 1.80 \\
\hline
\end{tabular}

TABLE VII

SF ANALYSIS OF GDC BRIDGE USING JANBU'S METHOD

\begin{tabular}{|l|l|}
\hline Location & SF \\
\hline Citayam & 1.26 \\
\hline GDC & 1.37 \\
\hline
\end{tabular}

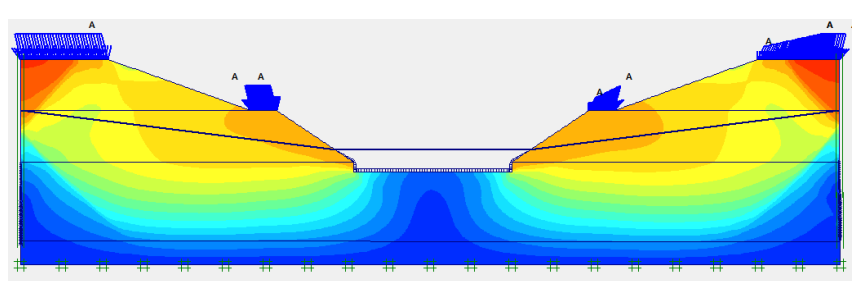

Fig. 3 Deformation analysis using Plaxis 8.2

TABLE VIII

SF ANALYSIS OF GDC BRIDGE USING THE GEO-SLOPE MODELING APPROACH

\begin{tabular}{|l|l|l|}
\hline Location & $\begin{array}{l}\text { SF without } \\
\text { seismic } \\
\text { condition }\end{array}$ & $\begin{array}{l}\text { SF with seismic } \\
\text { condition }\end{array}$ \\
\hline GDC_global collapse & 2.568 & 0.579 \\
\hline GDC-upper local collapse & 1.756 & 0.329 \\
\hline GDC-sub-local collapse & 1.739 & 0.717 \\
\hline Citayam-global collapse & 3.955 & 0.237 \\
\hline $\begin{array}{l}\text { Citayam-upper local } \\
\text { collapse }\end{array}$ & 2.242 & 1.066 \\
\hline $\begin{array}{l}\text { Citayam-sub-local } \\
\text { collapse }\end{array}$ & 1.205 & 0.375 \\
\hline
\end{tabular}

\section{Structural Mitigation: Reinforcement Analysis}

The challenges to disaster response and management are currently increasing [47]. Generally, the disaster risk management cycle has four stages, namely, prevention/mitigation, preparedness in the pre-disaster stage, emergency intervention, and recovery and reconstruction [48]. In the prevention/mitigation phase, efforts are made to prevent or mitigate damage. Previous research on slope reinforcement using anchor concluded that it provides a better reinforcement effect [49]. Meanwhile, Yang et al. [49] recommended analyzing the stress level and displacement field using numerical modeling to strengthen the achieved result.

This research introduces structural mitigation using a ground anchor. This study also proposes snail application to increase the SF of the slope using the SnailWin 3.10 modeling program. This program is a soil reinforcement program legislated by the California Department of Transportation. This program aims to increase the SF of the slope due to landslide potential. Given the high cost of snail or anchor, this research analyzes the use of two snails. The input data of this program are the soil data of GDC bridge. On the basis of the output of the SnailWin 3.0 program, the $\mathrm{SF}$ of the slope without reinforcement is 1.09, which increases to 2.05 when using the reinforcement program.

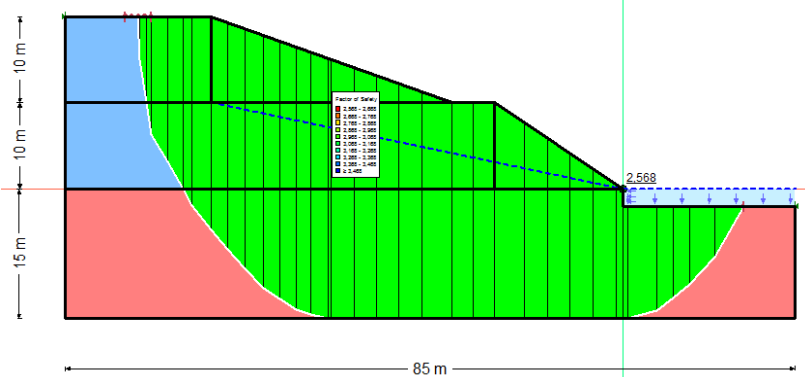

Fig. 4 GDC side without seismic condition (global collapse)

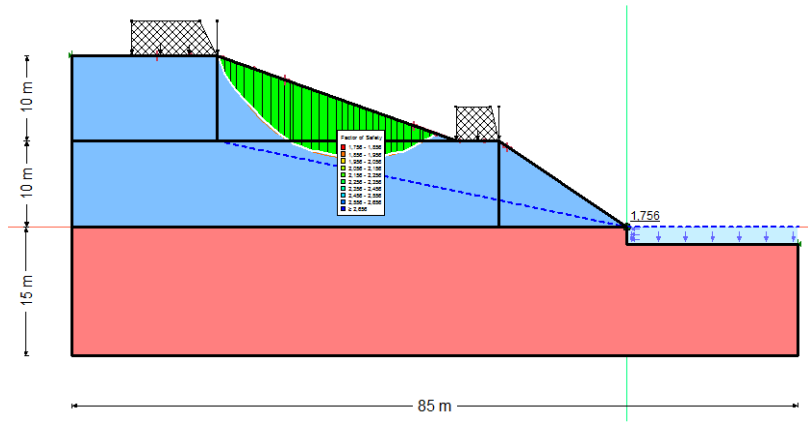

Fig. 5 GDC side without seismic condition (upper local collapse)

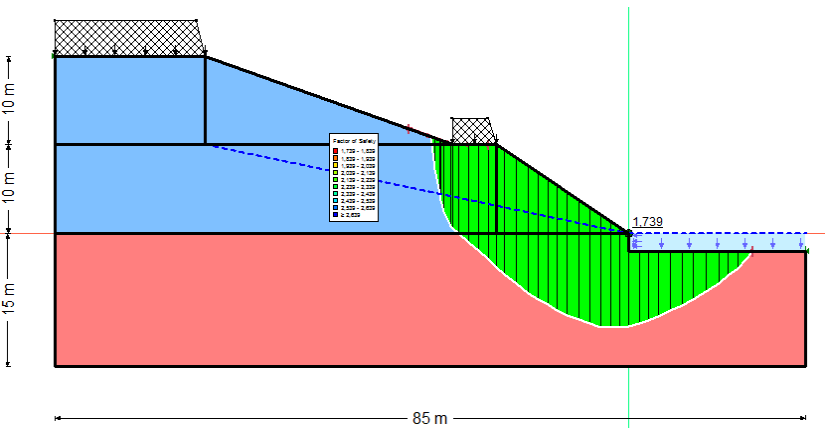

Fig. 6 GDC side without seismic condition (sub-local collapse)

The analysis of the total budget for reinforcement is based on Widyawati's calculation step [50]. Table 9 shows the budget plan for anchor reinforcement. On the basis of the total budget for the application of two groundwater anchors, 
it is not recommended for slope stability reinforcement. Several reasons support this suggestion. First, the SF of three observed locations is not at a critical point, i.e., it is still safe for the society and environment. Second, the soil nailing or anchor application method is inapplicable for high water surfaces. In this case, the Ciliwung River has a high water surface in the observed site. Finally, in addition to the high cost, the implementation of soil nailing or anchor application is complicated; thus, it needs some experts to make it happen.

TABLE IX

ANCHOR BUDGET PLAN

\begin{tabular}{|c|c|c|c|c|c|c|}
\hline Reinforcement component & Types & Amount & $\begin{array}{l}\text { Grouting } \\
\text { length or } \\
\text { volume }\end{array}$ & $\begin{array}{l}\text { Budget } \\
\text { (rupiah) }\end{array}$ & $\begin{array}{l}\text { Total } \\
\text { length (m) }\end{array}$ & $\begin{array}{l}\text { Total budget } \\
\text { (rupiah) }\end{array}$ \\
\hline \multirow{2}{*}{ Anchor } & $\begin{array}{l}\text { Without } \\
\text { subdrain }\end{array}$ & 2 & $9 \mathrm{~m}$ & 60.000 .000 & 34 & 4.080 .000 .000 \\
\hline & $\begin{array}{l}\text { With } \\
\text { subdrain }\end{array}$ & 2 & $8 \mathrm{~m}$ & 60.000 .000 & 34 & 4.080 .000 .000 \\
\hline \multirow{2}{*}{ Drilling } & $\begin{array}{l}\text { Without } \\
\text { subdrain }\end{array}$ & 2 & $9 \mathrm{~m}$ & 1.700 .000 & 34 & 115.600 .000 \\
\hline & $\begin{array}{l}\text { With } \\
\text { subdrain }\end{array}$ & 2 & $8 \mathrm{~m}$ & 1.700 .000 & 34 & 115.600 .000 \\
\hline \multirow{2}{*}{ Grouting } & $\begin{array}{l}\text { Without } \\
\text { subdrain }\end{array}$ & 2 & $0.29 \mathrm{~m}^{3}$ & 1.700 .000 & 34 & 33.524 .000 \\
\hline & $\begin{array}{l}\text { With } \\
\text { subdrain }\end{array}$ & 2 & $0.26 \mathrm{~m}^{3}$ & 1.700 .000 & 34 & 30.056 .000 \\
\hline \multirow{2}{*}{ Concrete plat } & $\begin{array}{l}\text { Without } \\
\text { subdrain }\end{array}$ & 2 & $1.3 \mathrm{~m}^{3}$ & 1.200 .000 & 34 & 106.080 .000 \\
\hline & $\begin{array}{l}\text { With } \\
\text { subdrain }\end{array}$ & 2 & $1.3 \mathrm{~m}^{3}$ & 1.200 .000 & 34 & 106.080 .000 \\
\hline \multicolumn{6}{|c|}{ Total budget without subdrain (rupiah) } & 4.335 .204 .000 \\
\hline \multicolumn{6}{|c|}{ Total budget with subdrain (rupiah) } & 4.331 .736 .000 \\
\hline
\end{tabular}

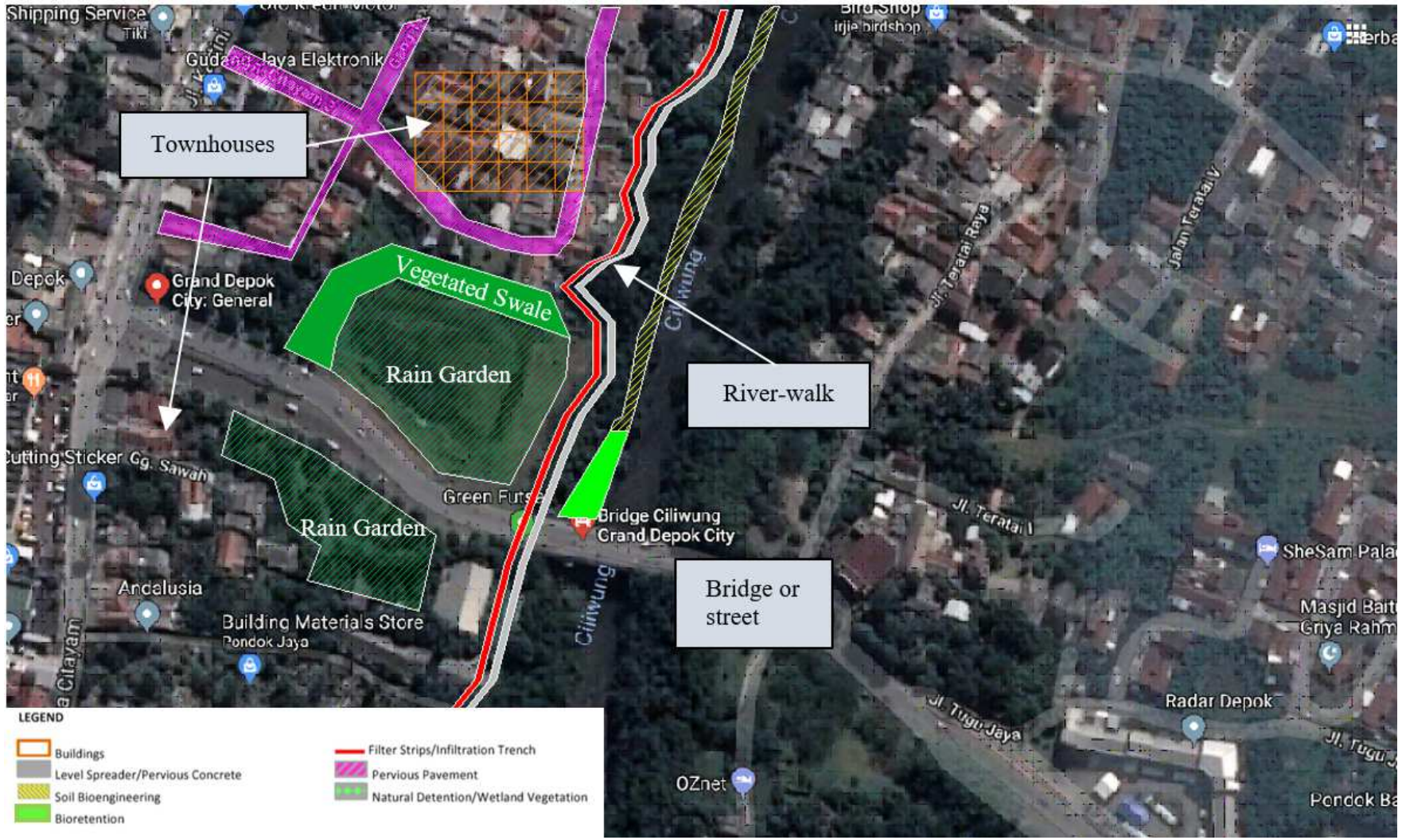

Fig. 7 Proposed green infrastructures in Ciliwung River's floodplain region 


\section{E. Green Infrastructure Mitigation}

Structural mitigation involves considerable expenditure to construct buildings. Another method proposed to mitigate water-related landslide is GI. GI, which is also known as soil bioengineering, has been recognized as an effective method for slope stabilization [51]. GI is a smart solution for today's needs. GI uses vegetation and soil for rainwater management [52]. GI has several eco-friendly benefits over structural infrastructure for landslide mitigation. GI could protect steep slopes by managing runoff before it flows downstream.

In the past decade, tsunamis have serious impacts on the environments of various countries. Previous research reported that coastal vegetation could reduce the impact of this disaster [53, 54]. For example, coastal vegetation helped mitigate the impacts of tsunami disaster on a coastal village in Chile [55]. This means that plants or GI increases an area's strength against water-related landslide disaster.

On the basis of the site condition, GI could intercept sheet flows if they settled at the top of the slope. Moreover, GI should be placed near impermeable areas to balance the infiltration of rainfall to the ground. GI could be in the form of permeable concrete pavement, infiltration trenches, vegetated swales, rain garden, soil bioengineering, bioretention, and wetland vegetation. It is better to choose soil bioengineering for river embankment instead of a concrete canal. The soil bioengineering concept mitigates the critical ecological condition in the site and strengthens the levee to be as safe as a concrete canal.

This research installs pervious concrete for pavements and green roof for buildings in the site to manage runoff. The study also plans to introduce infiltration trenches, bioretention, vegetated swales, and rain garden to protect the river's steep banks.

Fig. 7 shows the GI installation strategy. The main road site is divided by rain garden areas. The rain garden is located in two locations to manage runoff in the main road and river. Vegetated swales support the rain garden. The porous pavement is installed in the townhouses near the research site. Along the riverwalk, the infiltration trench is placed. Closer to the river, bioretention and soil bioengineering are established to manage the landslide probability of the slope. On the basis of its primary function, soil bioengineering alternatives support the survival of plants and river animals (e.g., macroinvertebrates) around the river.

On the basis of the slope stability analysis result, the minimum SF obtained from the simulation with various scenarios is normal. This means that the current condition of Ciliwung River's floodplain is safe. Historically, the evidence of landslide damage in that area does not indicate severe damage. The influence of settlement load does not significantly increase the landslide potential. The main factors that could cause landslides are groundwater fluctuation and water surface elevation of the river. The minimum SF is obtained if the maximum flood surface or maximum average of the water surface is applied to the simulation. Another factor that determines landslide potential is the slope. The more frequent the occurrence of rainfall is, the lower the SF of the slope. On the basis of the simulation conducted in this research, the upper slope becomes steeper because of erosion. Moreover, the lower slope tends to slope because of rainfall and river stream current scour. Thus, the high intensity of rain would increase the landslide potential of Ciliwung River's floodplain.

Structural mitigation, such as anchor or snail application, is too expensive for this case. A retaining wall is the structural mitigation method currently applied in the Ciliwung River. This retaining wall prevents scouring due to rainfall. This mitigation method is used downstream of the river to protect the settlement area around the river from damage. In this case, GI is highly recommended instead of structural relief. Furthermore, the proposed GI mitigation method should be analyzed in depth to obtain a more comprehensive result. For example, focus group discussion with the local community and stakeholders should be conducted to support the establishment of GI in particular regions in Ciliwung River's floodplain.

\section{CONCLUSION}

This research concludes that the minimum SF in the analyzed location is recognized as a safety criterion for society. Furthermore, high rainfall intensity could become the worst scenario that generates considerable damage. The proposed structural mitigation for river bank with anchor or snail increases the SF. However, this structural mitigation or reinforcement application is not recommended because of its high cost and ineffectiveness in solving problems. Hence, GI is highly suggested for nature-based mitigation to prevent RTL in the Ciliwung River area. Furthermore, a comprehensive analysis of GI or soil bioengineering should be conducted in the future to ensure its effectiveness and applicability in the research area.

\section{ACKNOWLEDGEMENT}

The authors wish to thank PITTA Research Grant of Universitas Indonesia Contract Number 2511/UN2.R3.1/HKP.05.00/2018 as part of this research funding. Rian Mantasa Salve Prastica expresses his appreciation as his master program was conducted by the scholarship of Indonesia Endowment for Education or Lembaga Pengelola Dana Pendidikan (LPDP) by the Ministry of Finance of Indonesia. Also, the first author delivers gratitude to Civil Engineering Department, Vocational College, Universitas Gadjah Mada.

\section{REFERENCES}

[1] M. T. Mia, N. Sultana, and A. Paul, "Studies on the Causes, Impacts and Mitigation Strategies of Landslide in Chittagong city, Bangladesh," J. Environ. Sci. \& Natural Resources, 8 (2): 1-5, 2015.

[2] P. Patra and R. Devi, "Assessment, prevention and mitigation of landslide hazard in the Lesser Himalaya of Himachal Pradesh," Environ. Scio.-econ. Stud., 3 (3), pp. 1-11, 2015.

[3] Z. Y. Chen, X. M. Meng, Y. P. Yin, T. Dijkstra, M. Winter, and J. Wasowski, "Landslide research in China," Quarterly Journal of Engineering Geology and Hydrogeology, 49, 4, 279-285, 2016.

[4] M. Klose, B. Damn, and B. Terhorst, "Landslide cost modeling for transportation infrastructures: A methodological approach," Landslides, 12(2), 321-334, March 2014.

[5] M. Del Soldato, S. Bianchini, D. Calcaterra, P. De Vita, D. D. Martire, R. Tomas, and N. Casagli, "A new approach for landslideinduced damage assessment," Geomat. Nat. Hazards Risk, 8(4), 1524-1537, July 2017.

[6] W. Meng, Y. Xu, W. Cheng, and A. Arulrajah, "Landslide event on 24 June in Sichuan Province, China: preliminary investigation and analysis," Geosciences, 8, 39, pp. 1-11, 2018. 
[7] M. Polemio and O, Petrucci, "Rainfall as a landslide triggering factor: an overview of recent international research," International Journal of Landslide, 3, 1219-1226, 2000.

[8] L. L. Zhang, J. Zhang, L. M. Zhang, and W. H. Tang, "Stability analysis of rainfall-induced slope failure: a review," Geotech Eng, 164 (GE5) : 299-316, 2010.

[9] Y. F. Cui, X. J. Zhou, and C. X. Guo, "Experimental study on the moving characteristics of fine grains in wide grading unconsolidated soil under heavy rainfall," J Mt Sci, 14 (3) : 417-431, 2017.

[10] I. W. Arya, I. W. Wiraga, and I. G. A. G. Suryanegara, "Effect of cement injection on sandy soil slope stability, case study: slope in Petang district, Badung regency," J. Phys.: Conf. Ser., vol. 953 012103, 2017.

[11] D. Caracciolo, E. Arnone, F. L. Conti, and L. V. Noto, "Exploiting historical rainfall and landslide data in a spatial database for the derivation of critical rainfall thresholds," Environ. Earth Sci., 76, 222, 2017.

[12] M. Ciurleo, L. Cascini, and M. Calvello, "A comparison of statistical and deterministic methods for shallow landslide susceptibility zoning in clayey soils," Eng. Geol., 223, 71-81, 2017.

[13] L. Cascini, M. Ciurleo, and S. Di Nocera, "Soil depth reconstruction for the assessment of the susceptibility to shallow landslides in finegrained slopes," Landslides, 14(2), 459-471, June 2016.

[14] F. Y. Zhang, C. Kang, D. Chan, X. C. Zhang, X. J. Pei, J. B. Peng, "A study of a flow slide with significant entrainment in loses areas in China," Earth Surf Process Landf, 42 (14) : 2295-2305, 2017.

[15] J. Wang, W. Jin, Y-f Cui, W-f Zhang, C-h Wu, and P. Alessandro, "Earthquake-triggered landslides affecting a UNESCO Natural Site: the 2017 Jiuzhaigou Earthquake in the World National Park, China," J Mt Sci, 15(7) : 1412-1428, 2018.

[16] S. Romeo, L. Di Matteo, L. Melelli, C. Cencetti, W. Dragoni, and A. Fredduzzi, "Seismic-induced rockfalls and landslide dam following the October 30, 2016 earthquake in Central Italy," Landslide, 14, 1457-1465, 2017.

[17] C. Qi, J. Qi, L. Li, and J. Liu, " Stability analysis method for rock slope with an irregular shear plane based on interface model," Advanced in Civil Engineering, vol. 2018 Article ID 8190908, pp. 18, 2018.

[18] R. V. Silviani, "The analysis of landslide danger and risk in upper Ciliwung watershed and its correlation with spatial management," Thesis, Institut Pertanian Bogor, Bogor, Indonesia, 2013.

[19] E. W. Brand, "Landslides in Hong Kong caused by the severe rainfall event of 8 May 1992", Landslide News, 7, 9-11, 1993.

[20] E. W. Brand, J. Premchitt, and H. B. Phillipson, "Relationships between rainfall and landslides in Hong Kong," Proc $4^{\text {th }}$ Symp. on Landslides, Toronto, 1, 377-384, 1984.

[21] M. Fukuoka, "Landslides associated with rainfall," Geotechnical Engineering, 11, 1-29, 1980.

[22] B. A. Morgan, G. F. Wieczorek, R. H. Campbell, and P. L. Gori, "Debris-flow hazards in areas affected by the June 27, 1995 storm in Madison County, Virginia," Open File Report: 97-438, 1997.

[23] W. Fellenius, "Calculation of the stability of earth dams," Proceedings of the 2nd International Congress on Large Dams, vol. 4, p. 445, Washington, DC, USA, 1936.

[24] A. W. Bishop, "The use of the slip circle in the stability analysis of slopes," Géotechnique, 5, 1, 7-17, 1955.

[25] N. R. Morgenstern, and V. E. Price, "The analysis of the stability of general slip surfaces," Géotechnique, vol. 15, no. 1, pp. 79-93, 1965

[26] E. Spencer, "A method of analysis of the stability of embankments assuming parallel inter-slice forces," Géotechnique, vol. 17, no. 1, pp. 11-26, 1967

[27] S. K. Sarma, S. K. "Stability analysis of embankments and slopes," Géotechnique, 23, no. 3, 423-433, 1973.

[28] J. M. Duncan, and A. L. Buchignani, "An Engineering Manual for Slope Stability Studies," Virginia Tech, Blacksburg, Va, USA, 1987.

[29] N. Janbu, "Slope stability computations", in Embankment Dam Engineering, R. C. Hirschfeld and S. J. P. John, Eds., 47-86, John Wiley \& Sons, New York, NY, USA, 1973.

[30] S. K. Sarma, "Stability analysis of embankments and slopes," Journal of the Géotechnical Engineering Division, 105, 12, 15111524,1979

[31] Zhao, Yun, Z-Y Tong, and Q Lü, "Slope stability analysis using slice-wise factor of safety," Mathematical Problems in Engineering, Volume 2014,pg. 1-6, 2014.

[32] E. M. Dawson, W. H. Roth, and A. Drescher, "Slope stability analysis by strength reduction," Géotechnique, vol. 49, no. 6, pp. 835-840, 1999.
[33] B. Hu, X, Wang, S. Li, J. Zhao, and N. M. Eugénie, "Stability analysis and confidence level evaluation of backfill mining under high and steep rock slopes," Advances in Civil Engineering, 2018 3029796, 1-12, 2018.

[34] C. Carranza-Torres, and E. Hormazabal, " Computational tools for the determination of factor of safety and location of the critical circular failure surface for slopes in Mohr-Coulomb dry ground," Slope stability 2018, Sevilla, Spain, 2018.

[35] T. D. S. Pereira, A. D. Robaina, M. X. Peiter, F. D. V. A. Braga, R B. Rosso, "Performance of analysis methods of slope stability for different geotechnical classes soil on earth dams," Journal of the Brazilian association of agricultural engineering. Eng. Agric. Jaboticabal, 36, 6, 1027-1036, 2016.

[36] S. Y. Liu, L. T. Shao, and H. J. Li, "Slope stability analysis using the limit equilibrium method and two finite element methods," Computers and Geotechnics, vol. 63, pp. 291-298, 2015.

[37] Fine Inc, GEO5, "Slope stability analysis software based on the limit equilibrium method," Praha, Czech Republic, 2016.

[38] Rocscience Inc., SLIDE Version 7, "Slope stability analysis software based on the limit equilibrium method," Toronto, Canada, 2015.

[39] Geo-Slope Inc., SLOPE/W Version 2012, "Slope stability analysis software based on the limit equilibrium method," Calgary, Canada, 2012.

[40] K. Terzhagi et. al., Soil Mechanics In Engineering Practice, 3rd Edition, New York: John Wiley \& Sons, 1996.

[41] A. W., Skempton, "Discussion: Further data on the c/p ratio in normally consolidated clays," in Proceedings of the Institution of Civil Engineers, vol. 7, pp. 305-307, 1957.

[42] L. Bjerrum, "Embankments on Soft Ground, State-of-the-Art Report," presented at the June 11-14, 1971, in ASCE Specialty Conference on Performance of Earth and Earth-Supported Structures, held at Lafayette, Ind., vol. 2, pp. 1-54, 1971.

[43] R. E. Gibson, "Experimental Determination of the True Cohesion and True Angle of Internal Friction in Clay," in Proc. $3^{\text {rd }}$ Int. Conf. ISSMFE Zurich, vol. 1, pp. 126-130, 1953.

[44] L. D. Wesley, "Shear strength properties of halloysite and allophone clays in Java, Indonesia," Gèotechnique, 27 (2), 125-136, 1977.

[45] M. Budhu, Soil Mechanics Fundamentals, United Kingdom: John Wiley \& Sons, Ltd, 1976.

[46] A. Kumar, V. George, and S. Marathe, "Stability analysis of lateritic soil embankment sub-grade using plaxis-2D," International Journal for Research in Civil Engineering, 2, 1, 1-8, 2016.

[47] H. Al-Dahasha, and U. Kulatunga, "Challenges facing the controlling stage of the disaster response management resulting from war operations and terrorism in Iraq," Procedia Engineering, 212, 863870, 2018.

[48] D. E. Alexander, "L'Aquila, central Italy, and the "disaster cycle", 2009-2017", Disaster Prevention and Management: An International Journal, 2018.

[49] G. Yang, Z. Zhong, Y. Zhang, X. Fu, "Optimal design of anchor cables for slope reinforcement based on stress and displacement fields," Journal of Rock Mechanics and Geotechnical Engineering, 7, 411-420, 2015.

[50] M. O. Widyawati, "The analysis of embankment strength for landslide case in Balikpapan Regional Hospital by using ground anchor and soldier pile," Thesis, Civil and Planning Engineering Faculty, Institut Teknologi Sepuluh Nopember, Surabaya, Indonesia, 2017.

[51] J. J. Ni, A. K. Leung, C. W. W. Ng, and W. Shao, "Modelling hydromechanical reinforcements of plants to slope stability," Computers and Geotechnics, 95, 99-109, 2018.

[52] S. Sarkar, J. B. Butcher, T. E. Johnson, and C. M. Clarck, "Simulated sensitivity of urban green infrastructure practices to climate change", Earth Interact, 22, 13, 1-37, June 2018.

[53] N. Tanaka, K. Ogino, "Comparison of reduction of tsunami fluid force and additional force due to impact and accumulation after collision of tsunami-produced driftwood from a coastal forest with houses during the Great East Japan tsunami," Landsc Ecol Eng,. 13, 287-304, 2017.

[54] N. Tanaka, A. Onai, "Mitigation of destructive fluid force on buildings due to trapping of floating debris by coastal forest during the Great East Japan tsunami," Landsc Ecol Eng, 13, 131-144, 2017.

[55] R. Rodriguez, P. Encina, M. Espinosa, N. Tanaka, "Field study on planted forest structures and their role in protecting communities against tsunamis: experiences along the coast of the Biobi'o region, Chile," Landsc Ecol Eng, 12, 1-12, 2016. 